\title{
The relationship between isolated pes equinovarus and aneuploidies and perinatal outcomes: Results of a tertiary center
}

\author{
İzole pes ekinovarus ile anöploidiler arasında ilişki ve perinatal \\ sonuçlar: Tersiyer tek merkez sonuçları
}

(1) Mete Sucu, (1) Süleyman Cansun Demir

Çukurova University Faculty of Medicine, Department of Obstetrics and Gynecology, Adana, Turkey

\begin{abstract}
Objective: Congenital pes equinovarus (PEV) is the most common congenital deformity of the foot, characterized by plantar flexion with a frequency of $0.2-0.3 \%$. It can be diagnosed from the $12^{\text {th }}$ week of pregnancy. Non-isolated cases tend to be syndromic and complex. We aimed to evaluate the results of perinatally diagnosed isolated PEV.

Materials and Methods: This was a retrospective cohort study conducted between March 2015-March 2020. Women who presented for fetal anomaly screening or were referred due to any suspected fetal anomaly were subjected to detailed fetal anomaly scans and checked for the presence of PEV. Karyotype analysis was discussed for patients with PEV. Pregnancy termination was recommended for those with chromosomal/life-threatening anomalies. The diagnosis was confirmed by postnatal examination/autopsy. Postnatal diagnosis was accepted as false-positive in those with no PEV.

Results: One-hundred thirty-eight patients were found to have PEV, 41 (29.7\%) of which were isolated. In the isolated group, the false-positive rate in the first trimester was significantly higher compared with the second trimester, 50\%/15.3\%, respectively ( $\mathrm{p}<0.05)$. Chromosomal anomalies were detected in $2(4.8 \%)$ patients in the isolated group. Termination was performed to $1(2.4 \%)$ patients due to trisomy 21 . In the non-isolated group, chromosomal anomalies were detected in $13(13.4 \%)$ patients, and termination was recommended. Termination was also recommended to 18 (18.5\%) patients due to anomalies incompatible with life. In the postnatal evaluation, the surgical treatment rate in the isolated/non-isolated groups was 6\%/39.7\% (p<0.05).

Conclusion: When PEV is diagnosed, detailed fetal anomaly screening must be performed, patients should be informed about the chromosomal anomaly risk. High false-positive rates in the first trimester should be kept in mind for diagnosis. Karyotype analysis should be recommended also to isolated cases. It should be remembered that some neuromuscular/skeletal system anomalies may occur for the first time in the postnatal period in isolated cases.

Keywords: Clubfoot, Down syndrome, diagnostic imaging, karyotyping

Öz

Amaç: Konjenital pes ekinovarus (PEV), ayağın en sık görülen konjenital deformitesidir, aşırı plantar fleksiyon ile karakterizedir ve 1000 canlı doğumda 2-3 sıklıkla görülür. Gebeliğin 12. haftasından itibaren teşhis etmek mümkündür. İzole olmayan olgular sendromik ve daha karmaşık olma eğilimindedir. Çalışmamızda, perinatal dönemde teşhis edilen izole PEV olgularının sonuçlarını değerlendirmeyi amaçladık.

Gereç ve Yöntemler: Çalışmamız Mart 2015-Mart 2020 tarihleri arasında yürütülen retrospektif kohort çalışmasıdır. Rutin fetal anomali taraması için başvuran veya herhangi şüpheli fetal anomali nedeniyle sevk edilen kadınlar, ayrıntılı bir fetal anomali taramasına tabi tutuldu, PEV varlığı ve eşlik eden anomaliler açısından kontrol edildi. PEV saptanan hastalarla karyotip analizi tartışıldı. Kromozom anomalisi veya hayatı tehdit eden anomalisi olanlara gebelik terminasyonu önerildi. Tanı postnatal muayene veya otopsi ile doğrulandı. Postnatal PEV saptanmayanlarda tanı yanlış pozitif olarak kabul edildi. Bulgular: Yüz otuz sekiz hastada PEV saptandı. Kırk biri $(\% 29,7)$ izole idi. İzole grup içinde, ilk trimesterde yanlıs pozitiflik oranı ikinci trimester ile kıyaslandığında anlamlı derecede yüksekti sırasıyla \%50 ve \%15,3 (p<0,05). İzole grupta $2(\% 4,8)$ hastada kromozomal anomali tespit edildi. Bir $(\% 2,4)$ hastaya trizomi 21 nedeniyle terminasyon uygulandı. Non-izole grupta $13(\% 13,4)$ hastada kromozom anomalisi saptandı ve terminasyon önerildi. Ayrıca $18(\% 18,5)$ hastaya yaşamla bağdaşmayan anomaliler nedeniyle gebelik termiansyonu önerildi. Postnatal değerlendirmede izole ve non-izole grupta cerrahi tedavi oranı sırası ile \%6 ve \%39,7 idi ve aradaki fark istatiksel olarak anlamlıydı $(\mathrm{p}<0,05)$.
\end{abstract}

PRECIS: We aimed to evaluate the perinatal and neonatal results of pregnant women who were found to have isolated PEV during the first and second trimester ultrasonographic screening in our clinic.

Address for Correspondence/Yazıșma Adresi: Mete Sucu MD,

Çukurova University Faculty of Medicine, Department of Obstetrics and Gynecology, Adana, Turkey

Phone: +90 5056176538 E-mail: metesucu@yahoo.com ORCID ID: orcid.org/0000-0002-6889-7147

Received/Geliș Tarihi: 29.11.2020 Accepted/Kabul Tarihi: 30.11.2020

${ }^{\circledR}$ Copyright 2020 by Turkish Society of Obstetrics and Gynecology

Turkish Journal of Obstetrics and Gynecology published by Galenos Publishing House. 
Sonuç: PEV teşhisi konduğunda, eşlik eden anomaliler için ayrıntılı bir fetal anomali taraması yapılmalı ve hastalar artan kromozomal anomali riski hakkında bilgilendirilmelidir. Tanı için ilk trimesterdeki yüksek yanlış pozitiflik oranları akılda tutulmalıdır. İzole olgulara da karyotip analizi önerilmelidir. Bazı nöromüsküler ve iskelet sistemi anomalilerinin, izole olgularda ilk kez doğum sonrası dönemde ortaya çıkabileceği hatırlanmalıdır.

Anahtar Kelimeler: Çarpık ayak, Down sendromu, tanısal görüntüleme, karyotipleme

\section{Introduction}

Congenital pes equinovarus (PEV) or clubfoot is a congenital malformation characterized by excessive plantar flexion of one foot or both feet, inward tilting of the heel, and adduction of the forefoot ${ }^{(1)}$. It is seen with a frequency of 2-3 per 1000 live births and is the most common congenital deformity of the foot ${ }^{(2)}$. It can be unilateral or bilateral, and its incidence in male fetuses is 2 times higher ${ }^{(3)}$.

Although the diagnosis of congenital PEV is usually made from the second trimester with ultrasonography (Figure 1), it is possible to diagnose it from $12^{\text {th }}$ week in the late first trimester ${ }^{(4)}$. Congenital PEV can be diagnosed more frequently through the development of ultrasound technology and the increase in the skills of physicians over time.

Syndromic cases tend to be more complex, and their association with other congenital malformations and/or chromosomal and genetic anomalies is common. It has been associated with some aneuploidies, deletion syndromes, sex chromosome abnormalities, neuromuscular disorders, microdeletion and duplications. Despite advances in molecular gene studies, a major causative gene has not been identified and clinical features of even familial cases show heterogeneity ${ }^{(5)}$.

Positional PEV is mostly associated with intrauterine factors limiting fetal movements, such as oligohydramnios, twin pregnancy and uterine anomalies. Early amniocentesis is one of the iatrogenic reasons that may lead to this ${ }^{(6)}$. There may be accompanying anomalies or it can be seen as isolated. Idiopathic PEV is usually isolated and generally have a good prognosis,

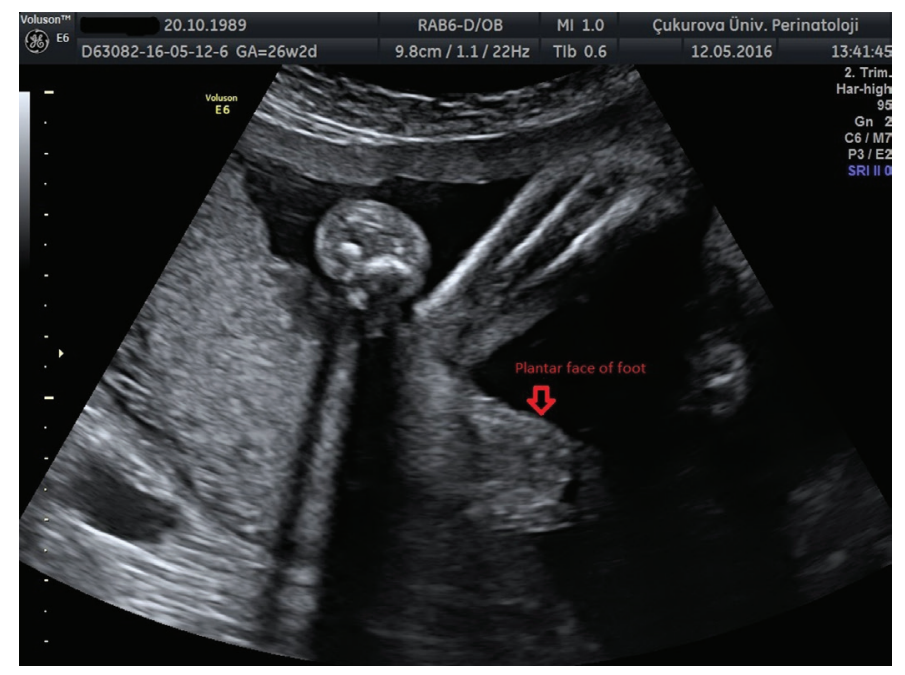

Figure 1. PEV ultrasonography image

PEV: Pes equinovarus their relationship with chromosomal anomalies is limited, and familial cases have been reported ${ }^{(5)}$. The fact that it has a higher prevalence in some populations and that it is more common among the male sex suggests that it is the result of a polygenetic predisposition $^{(4)}$

Environmental and genetic factors are thought to play a role in the etiology. It has been shown that maternal smoking, increased body mass index (BMI) and selective serotonin reuptake inhibitor use in the first trimester increases the risk of congenital $\mathrm{PEV}^{(7-9)}$. It was reported that Lamotrigine exposure during the prenatal period increased the risk of congenital PEV ${ }^{(10)}$

Conservative treatment is the primary method recommended in PEV treatment. Surgery is recommended for patients who do not respond to conservative treatment or who are late for treatment. Untreated patients may experience limitation of motion, deformity, and pain in the long term. Conservative methods include corrective splints (Ponseti or Kite's method), physiotherapy, and serial manipulations ${ }^{(11,12)}$. The surgical method may vary depending on the severity of the clinical course and accompanying anomalies ${ }^{(13)}$.

In this study, we aimed to evaluate the perinatal, neonatal and orthopedic results of pregnant women who were found to have isolated PEV during the first and second-trimester ultrasonographic screening in our clinic.

\section{Materials and Methods}

This study was a retrospective cohort study conducted in the Perinatology Unit of Çukurova University Faculty of Medicine, Department of Obstetrics and Gynecology, between March 2015 and March 2020. Patients who presented to our clinic for routine first-trimester and second-trimester fetal anomaly screening and patients referred to our clinic due to any suspected fetal anomaly or positive screening test were included in this study. Among the patients admitted in the first trimester, those between 12 and 14 weeks were included in the study. All patients were subjected to a detailed fetal anomaly scan and checked for the presence of PEV. Sonographic examinations of all patients were performed by four researchers experienced in fetal anomaly screening using a transabdominal 4-8- $\mathrm{MHz}$ probe with a Voluson E6 (GE Medical Systems, Zipf, Austria) device, and information of all patients was recorded on the Microsoft Viewpoint (GE Medical Systems) data recording system. Information of the patients and accompanying anomalies were obtained retrospectively from patient files and Microsoft Viewpoint (GE Medical Systems) program. This study comprised a heterogeneous patient group including high and 
low-risk patients. Approval for the study was obtained from the Ethics Committee of Çukurova University Medical Faculty (Registration number: 02.02.2018-74-1). Written informed consent was obtained from all patients.

When PEV was detected, fetal karyotyping was recommended to all patients by performing amniocentesis. Termination of pregnancy was recommended for patients that were detected to have karyotype anomalies and/or severe life-threatening anomalies. Patients whose pregnancy was terminated were not included in the postnatal evaluation. All patients were examined by a pediatrician and an orthopedist after birth. Patients who had no PEV in the neonatal examination were considered as false-positive and they were excluded from the postnatal evaluation. In patients with suspected findings of chromosomal anomalies in postnatal examinations, this was confirmed by karyotype analysis in peripheral blood. In the absence of suspected findings, the karyotype was accepted as normal.

\section{Statistical Analysis}

All information including the gestational week at the time of diagnosis, maternal age, BMI, accompanying anomalies, karyotype results, birth week, mode of delivery, and post-natal results were recorded and analyzed. Statistical analysis was performed using the Microsoft SPSS Excel program. The chisquare test was used for comparisons. P-values of $<0.05$ were considered statistically significant.

\section{Results}

During the study period, 7680 patients who presented for routine first and second-trimester fetal ultrasonography screening or who were referred to our clinic due to any suspected fetal anomalies or positive screening tests were examined. One hundred thirty-eight patients with congenital PEV were included in the study. In 41 (29.7\%) patients, no accompanying fetal anomalies were observed. In 97 (70.3\%) patients, there were some additional fetal anomalies together with PEV. The majority of the patients were diagnosed in the second trimester [128/138 (92.7\%)]. Patients diagnosed in the late first trimester (12-13 weeks and 6 days) constituted $7.3 \%$ (10/138). Sixty-four (65.9\%) patients in the non-isolated group agreed to undergo amniocentesis and chromosomal anomalies were detected in 13 patients. Termination of pregnancy was recommended for 31 patients in the non-isolated group due to severe anomalies. The distribution of these severe anomalies in the non-isolated group was as follows: trisomy 18 in nine patients, trisomy 21 in three patients, trisomy 13 in one patient, neural tube defect in 11 patients, lethal skeletal dysplasia in four patients, and major cardiac anomalies in three patients. Of the 31 patients for whom termination was recommended, 29 accepted the termination. The pregnancy of the remaining 68 patients was followed-up until delivery. Nineteen (46.3\%) patients in the isolated group agreed to undergo amniocentesis and chromosomal anomalies were detected in two patients (trisomy 21 in one patient, $47 \mathrm{XXY}$ in one patient). Pregnancy termination was performed to one (2.4\%) patient in the isolated group due to trisomy 21.

PEV was unilateral in 58 (42\%) patients and bilateral in 80 (58\%) patients. The rate of unilaterality was $41.4 \%(17 / 41)$ in the isolated group and was $42.2 \%$ (41/97) in the non-isolated group, the difference was not statistically significant $(p<0.05)$. The clinical course of patients diagnosed as having PEV in the prenatal period is summarized in Figure 2.

In the postpartum evaluations (examination and autopsy) performed to confirm the diagnosis of PEV, it was found that some fetuses did not have PEV. When the isolated group and the non-isolated group were compared for false positivity, the false-positive rate was significantly higher in the isolated group (Table 1). The rate of false positivity in the isolated group was found as $17 \%(7 / 41)$. When the isolated group was divided into unilateral and bilateral subgroups and examined, falsepositive rates were similar. In the non-isolated group, the rate of false-positives was 5.1\% (5/97), and the rate in the unilateral and bilateral subgroups was $9.7 \%(4 / 41)$ and $1.7 \%(1 / 56)$, respectively. The difference between the percentages was not statistically significant $(\mathrm{p}>0.05)$.

When the false-positive rates were evaluated according to the week of gestation at the time of diagnosis, the false-positive rates were detected to be significantly higher in the first trimester (Table 2). False positivity was detected in three (30\%) of 10 patients diagnosed as having PEV in the first trimester, and nine (7\%) of 128 patients diagnosed at the second trimester were found to be false positives. The false-positive rate in the isolated group was up to $50 \%$ in the first trimester (Table 2).

When the sex distribution was examined after removing the false-positive cases, the percentage of male fetuses in the isolated and non-isolated groups was $64.7 \%$ (22/34) and 66.3\% (61/92), respectively, similar to each other and almost twice higher than that of female fetuses.

When compared for characteristic features, no significant difference was found between isolated and non-isolated groups in terms of age, BMI, conception type, unilaterality/bilaterality, mode of delivery, and sex distribution. The clinical features of patients with PEV diagnosed during the prenatal period are shown in Table 3. The mean gestational week at the time of diagnosis, the mean birth week, and mean birth weight was significantly lower in the non-isolated group (Table 3). The rate of pregnancy termination was $2.9 \%$ in the isolated group, whereas it was $31.5 \%$ in the non-isolated group, the difference was statistically significant $(p<0.05)$. The rate of need for intensive care in the neonatal period was 10\% in the isolated group, whereas it was $44 \%$ in the non-isolated group, the difference was statistically significant $(\mathrm{p}<0.05)$. In the neonatal examination, suspicious findings for chromosomal anomalies were found in two patients in the non-isolated group, and they 
were confirmed by karyotype analysis in peripheral blood. Trisomy 21 was detected in one patient and $47 \mathrm{XXY}$ in one patient.

When the frequency of chromosomal anomalies was evaluated according to unilaterality or bilaterality, it was found as $5.88 \%$
(3/51) in the unilateral group and 20\% (15/75) in the bilateral group, the difference was statistically significant $(\mathrm{p}<0.05)$.

Trisomy 21 was detected in 51 patients in the entire study group [0.66\% (51/7680)]. In five of 51 fetuses with trisomy $21,9.8 \%$ (5/51) had PEV. After the elimination of patients with trisomy

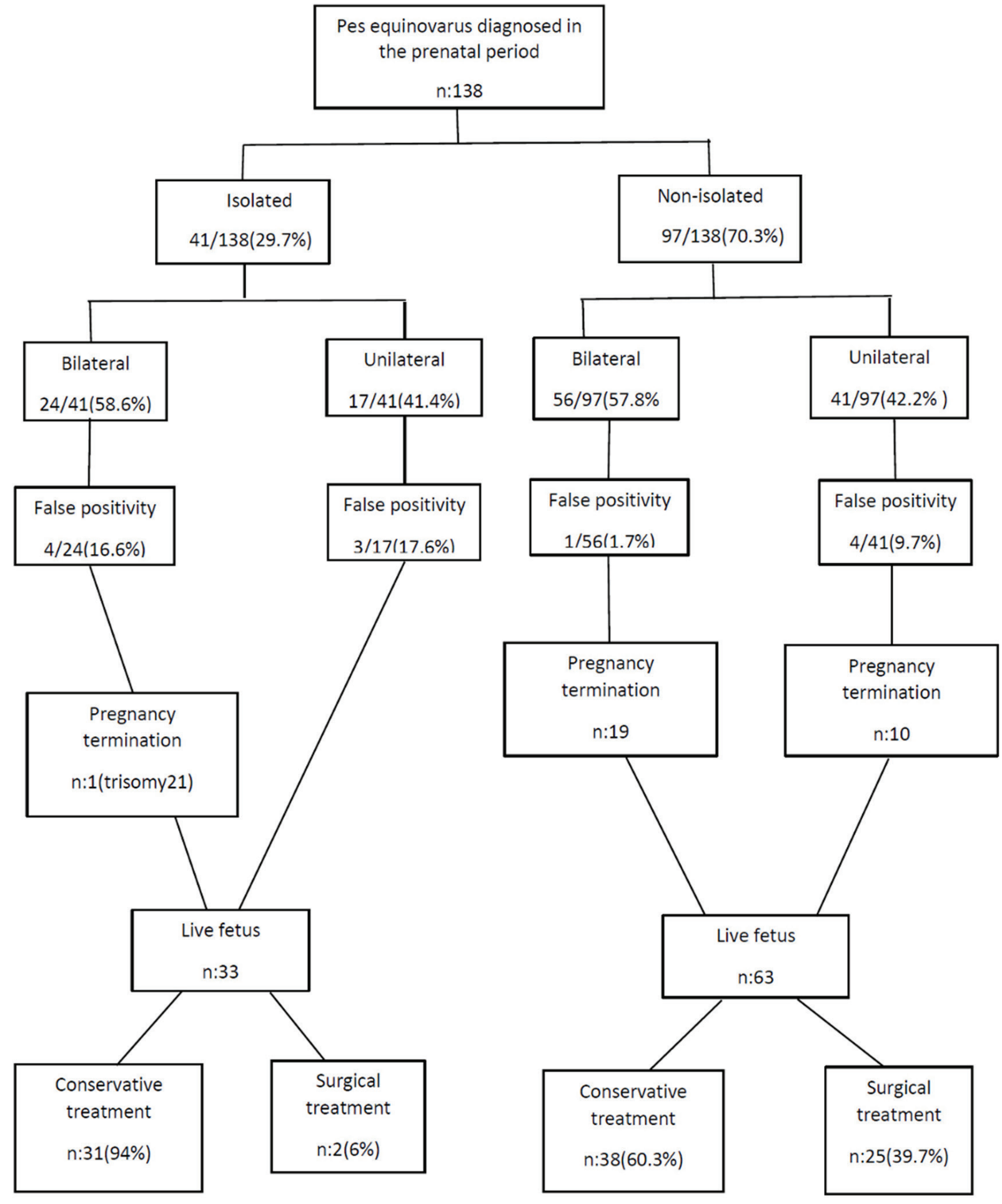

Figure 2. Clinical course of PEV cases diagnosed in the prenatal period PEV: Pes equinovarus 
Table 1. Distribution of postnatal false positivity rate of PEV due to laterality in antenatally diagnosed isolated and non-isolated groups

\begin{tabular}{llll|} 
& Unilateral & Bilateral & Total \\
\hline Isolated $(\mathrm{n}=41)$ & $3 / 17(16.6 \%)$ & $4 / 24(17.6 \%)$ & $7 / 41(17 \%)$ \\
$\begin{array}{l}\text { Non-isolated } \\
(\mathrm{n}=97)\end{array}$ & $4 / 41(9.7 \%)$ & $1 / 56(1.7 \%)$ & $5 / 97(5.1 \%)$ \\
\hline P-value* & & $<0.05$ \\
\hline *chi-square test was used, PEV: Pes equinovarus &
\end{tabular}

Table 2. Postnatal false positivity distribution according to the gestational week at the time of antenatal diagnosis in the isolated and non-isolated groups

\begin{tabular}{|llll|} 
& $\begin{array}{l}\text { First } \\
\text { Trimester }\end{array}$ & $\begin{array}{l}\text { Second } \\
\text { Trimester }\end{array}$ & p-value* \\
\hline Isolated $(\mathrm{n}=41)$ & $1 / 2(50 \%)$ & $6 / 39(15.3 \%)$ & $<0.05$ \\
\hline Non-isolated $(\mathrm{n}=97)$ & $2 / 8(25 \%)$ & $3 / 89(3.3 \%)$ & $<0.05$ \\
\hline Total $(\mathrm{n}=138)$ & $3 / 10(30 \%)$ & $9 / 128(7 \%)$ & $<0.05$ \\
\hline *chi-square test was used & & & \\
\hline
\end{tabular}

21 in the entire group, the PEV rate was calculated as 1.58\% (121/7639). The rate of trisomy 21 in patients with PEV was $3.96 \%(5 / 126)$. However, the rate of trisomy 21 in the group without PEV was found as $0.6 \%(46 / 7554)$. This indicates a 6.6-fold increase in the risk for trisomy 21 in patients with PEV. Thirty-one (94\%) patients in the isolated PEV group responded to conservative treatment. Conservative treatment was performed on $38(60.3 \%)$ patients in the non-isolated group; the difference was statistically significant $(\mathrm{p}<0.05)$. The conservative treatment rate was statistically significantly higher in the isolated group $(p<0.05)$. Surgical treatment was performed on patients who did not respond to conservative treatment or who were late for treatment. Corrective casting (Ponseti) and physiotherapy were used in conservative treatment. In terms of surgery, the most preferred methods were achillotomy and posteromedial release surgery.

\section{Discussion}

First-trimester and second-trimester fetal anomaly screening are recommended to all pregnant women during antenatal follow-up. Although PEV incidence is stated as $0.2-0.3 \%$ in the literature, the results in our study were far from these values, as some of the patients were referred. Although the diagnosis of PEV is usually made in the second trimester, Keret et al. ${ }^{(4)}$ showed that it was possible to make a diagnosis from the $12^{\text {th }}$ week in the first trimester. However, the diagnosis made in the first trimester has some drawbacks. Bogers et al. ${ }^{(14)}$ showed that there was a temporary PEV position during the normal development of the lower extremity in the first trimester and this development continued until the $13^{\text {th }}$ week. Diagnoses made without waiting for this physiologic positional change will cause an increase in false positivity. In our study, the rate of false positivity in the entire group was 12/138 (8.69\%). The false-positive rate was statistically significantly higher in patients in the first trimester than in the second trimester $(30 \%$ vs. $7 \%)(p<0.05)$. In the isolated group, the false-positive rate was found as $7 / 41(17 \%)$, reaching $50 \%$ in the first trimester. In the literature, this rate varies between $0 \%$ and $40 \%$ for isolated cases ${ }^{(15-18)}$. Our findings were similar to the literature. However, in the isolated group, 50\% false positivity in patients diagnosed in the first trimester draws attention, which can be explained by the fact that the patients in the isolated group were milder and by the physiologic position change of the foot in the first trimester. Due to high false-positive rates, isolated cases,

Table 3. Clinical features of PEV patients diagnosed in the prenatal period

\begin{tabular}{|l|l|l|l|}
\hline & $\begin{array}{l}\text { Isolated } \\
\mathrm{n}=34\end{array}$ & $\begin{array}{l}\text { Non-isolated } \\
\mathrm{n}=92\end{array}$ & p-value* \\
\hline Age & $25.32 \pm 4.25$ & $26.12 \pm 4.72$ & 0.193 \\
BMI & $28.3(21.0-33.0)$ & $25.9(18.0-31.2)$ & 0.396 \\
\hline
\end{tabular}

Conception method

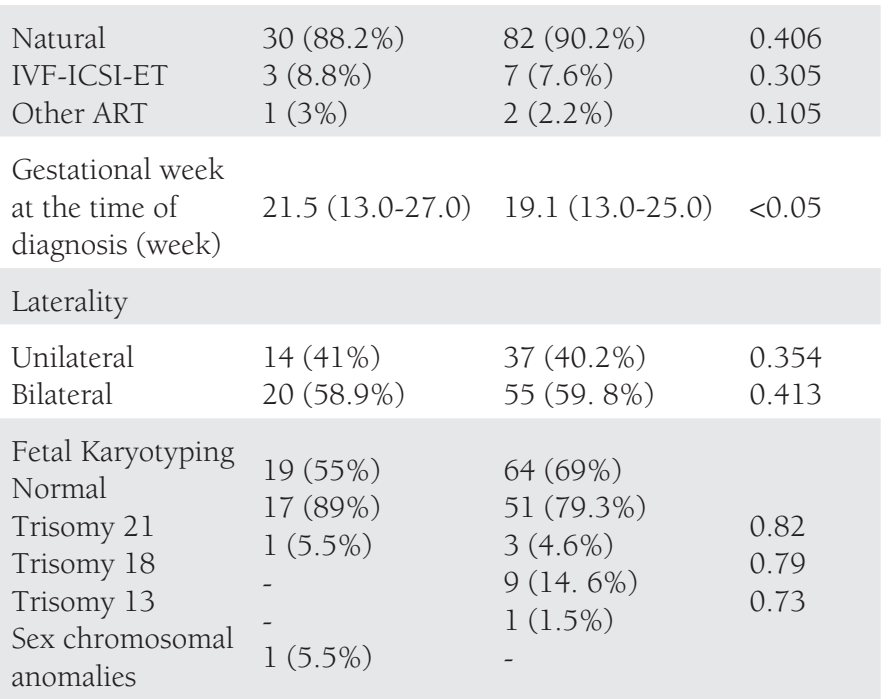

Pregnancy result

$\begin{array}{llll}\begin{array}{l}\text { Pregnancy } \\ \text { termination }\end{array} & 1(2.9 \%) & 29(31.5 \%) & <0.05 \\ \begin{array}{l}\text { Delivery } \\ \text { Vaginal birth }\end{array} & 15(97.1 \%) & 63(68.5 \%) & <0.05 \\ \text { Caesarean } & 18(54.5 \%) & 26(41.2 \%) & 0.31 \\ \text { Birth week } & 38.2(35.0-39.5) & 35.0(24.6-39.3) & <0.05 \\ \text { Birth weight } & 3230 & 1715(595-3770) & <0.05 \\ \text { Sex } & (1610-3850) & & \\ \text { Girl } & & & 0.42 \\ \text { Boy } & 12(35.3 \%) & 31(33.7) & 0.24\end{array}$

Neonatal

intensive care $\quad 3(10 \%) \quad 28(44 \%) \quad<0.05$ need

*chi-square test was used, PEV: Pes equinovarus, BMI: Body mass index 
especially those diagnosed in the first trimester, should be followed up with serial examinations to confirm the diagnosis. In this study, the median gestational week at the time of diagnosis of PEV was determined as 21.5 and 19.1 for the isolated and non-isolated groups, respectively. This can be explained by the fact that the disease is more complex and severe in the presence of accompanying anomalies and therefore can be diagnosed earlier ${ }^{(15,19,20)}$. Hartge et al. ${ }^{(21)}$ reported the median gestational week at the time of diagnosis as 23 weeks.

Postnatal examinations allow the detection of accompanying findings that could not be found in the prenatal period. Hence, in the non-isolated group, chromosomal anomalies were found in two patients who did not undergo amniocentesis during the antenatal period (trisomy 21 in one patient, $47 \mathrm{XXY}$ in one patient). In the isolated group, no additional anomalies and chromosomal anomalies were found in the postnatal period. Lauson et al. ${ }^{(22)}$ stated that neurologic, developmental, and additional structural anomalies could be detected in postnatal follow-up in isolated cases. In their studies, it was observed that $10 \%$ of isolated cases turned into complex cases after a minimum of 1-year follow-up. Di Mascio et al. ${ }^{(20)}$ reported that anomalies related to the skeletal system and neuromuscular system were detected at a rate of $7 \%$ in the postnatal follow-up of patients diagnosed as having isolated PEV in the prenatal period. Offerdal et al..$^{(15)}$ made a minimum of 2-years follow-up and found that $15 \%$ of the cases turned into complex cases. Shipp and Benacerraf ${ }^{(16)}$ found higher rates in their study. Our study has limitations in this regard because we have not yet followed-up all patients for at least one year.

Our sex distribution (boy/girl) in isolated PEV cases was 2:1, which was consistent with the literature. In our study, the percentage of non-isolated PEV was $73 \%$. Although this rate varies between $48 \%$ and $51 \%$ in some community studies, rates up to $80 \%$ have been reported in tertiary centers such as our clinic where high-risk patients are treated ${ }^{(15,17,23)}$.

In our study, although chromosome anomalies were detected with a rate of $5.8 \%$ in the isolated group, the rate was 16.3\% in the non-isolated group. Many authors believe that karyotype is necessary in the presence of anomalies accompanying PEV; however, there are ongoing discussions for isolated cases $^{(24,25)}$. The most common chromosomal anomalies associated with PEV are trisomies 13 and 18. It is possible to recognize cases with trisomy 13 and 18 using ultrasonography due to accompanying anomalies. However, sex chromosome anomalies and trisomy 21 sometimes display very limited or no findings. For this reason, especially in isolated PEV cases, karyotyping comes to the fore due to the risk of trisomy 21. In the study of Viaris et al. ${ }^{(26)}$, the rate of chromosomal anomalies in the isolated group was $2.2 \%$. Lauson et al. ${ }^{(22)}$ reported the incidence of chromosomal anomalies as $2.3 \%$ in the isolated group. Recommending karyotype to isolated cases in the presence of advanced maternal age or positive screening test should not be avoided $^{(20)}$. PEV was detected in five of 51 patients with trisomy 21 in our study population (9.8\%). This situation increases the risk of trisomy 21 in patients with PEV 6.6 times. Offerdal et al. ${ }^{(15)}$ detected aneuploidy at the rate of $13 \%$ in patients with PEV and showed that there was a strong relationship between PEV and chromosomal anomalies, and they recommended karyotyping for all patients including isolated cases. Tegnanader and Eik-Nes ${ }^{(27)}$ reached similar results.

According to the findings of Bakalis et al. ${ }^{(17)}$, the prognosis was worse and the frequency of chromosomal anomalies was higher in the bilateral group, similar to our study. In the study of Viaris et al. ${ }^{(26)}$, no difference was found between the two groups.

Despite the high incidence of PEV, only a few causative genes are known. PITX1 (MIM 602149), IGFBP3 (MIM 146732), TBX4, and RBM10 genes have been found to be associated with isolated $\mathrm{PEV}^{(28-30)}$. Recommending chromosomal microarray studies in addition to conventional karyotyping to patients with PEV will help to better understand the factors causing the disease because multigenetic factors play a role in the etiology ${ }^{(20)}$.

Conservative treatment is the primary method recommended in the treatment of PEV. Surgery is recommended for patients who do not respond to conservative treatment. There is no treatment in the prenatal period. The accepted method in conservative treatment is Ponseti casting (12). In our cases, surgical treatment was performed on two patients (6\%) in the isolated group and $25(39.8 \%)$ patients in the non-isolated group, the difference was statistically significant $(\mathrm{p}<0.05)$. Careful fetal anomaly screening performed to detect accompanying anomalies will help us understand whether the cases are isolated and predict the postnatal prognosis.

\section{Study Limitations}

The limitations of this study are that it had a retrospective design, only patients diagnosed during the intrauterine period could be reached, and the rate of PEV detection could not be specified due to the exclusion of patients diagnosed for the first time in the postnatal period.

Another limitation is that only conventional karyotyping could be performed in patients, chromosomal microarray was not performed. Studies involving chromosomal microarray evaluations are needed to better understand the etiology of the disease.

\section{Conclusion}

The diagnosis of PEV can be made in the late first and second trimesters. In the first trimester, the rate of false positivity is higher, and the diagnosis should be confirmed with serial examinations. When PEV is diagnosed, detailed fetal anomaly screening should be performed for anomalies that may accompany, and patients should be informed about the 
increased incidence of chromosomal anomalies, and karyotype and chromosomal microarray analysis should be recommended. Chromosomal microarray can identify clinically significant chromosome abnormalities (gains and losses of DNA) that are below the resolution of conventional chromosome analysis. The risk of this chromosomal and structural anomaly further increases in the presence of accompanying additional findings. It should be kept in mind that some neuromuscular and skeletal system anomalies may occur for the first time in the postnatal period in isolated cases.

\section{Ethics}

Ethics Committee Approval: Approval for the study was obtained from the Ethics Committee of Çukurova University Medical Faculty (Registration number: 02.02.2018-74-1).

Informed Consent: Written informed consent was obtained from all patients.

\section{Authorship Contributions}

Surgical and Medical Practices: S.C.D., Concept: M.S., Design: M.S., Data Collection or Processing: M.S., Analysis or Interpretation: S.C.D., Literature Search: S.C.D., Writing: S.C.D.

Conflict of Interest: No conflict of interest was declared by the authors.

Financial Disclosure: Authors have no financial interests about the research.

\section{References}

1. Lochmiller C, Johnston D, Scott A, Risman M, Hecht JT. Genetic epidemiology study of idiopathic talipes equinovarus. Am J Med Genet 1998;79:90-6.

2. Sharon-Weiner M, Sukenik-Halevy R, Tepper R, Fishman A, Biron-Shental T, Markovitch O. Diagnostic accuracy, work-up, and outcomes of pregnancies with clubfoot detected by prenatal sonography. Prenat Diagn 2017;37:754-63.

3. Alderman BW, Takahashi ER, LeMier MK. Risk indicators for talipes equinovarus in Washington State, 1987-1989. Epidemiology 1991;2:289-92.

4. Keret D, Ezra E, Lokiec F, Hayek S, Segev E, Wientroub S. Efficacy of prenatal ultrasonography in confirmed club foot. J Bone Joint Surg Br 2002;84:1015-9.

5. Basit S, Khoshhal KI. Genetics of clubfoot; recent progress and future perspectives. Eur J Med Genet 2018;61:107-13.

6. Sanzarello I, Nanni M, Faldini C. The clubfoot over the centuries. J Pediatr Orthop B 2017;26:143-51.

7. Pavone V, Chisari E, Vescio A, Lucenti L, Sessa G, Testa G. The etiology of idiopathic congenital talipes equinovarus: a systematic review. J Orthop Surg Res 2018;13:206.

8. Wemakor A, Casson K, Garne E, Bakker M, Addor MC, Arriola L, et al. Selective serotonin reuptake inhibitor antidepressant use in first trimester pregnancy and risk of specific congenital anomalies: a European register-based study. Eur J Epidemiol 2015;30:1187-98.

9. Yazdy MM, Mitchell AA, Louik C, Werler MM. Use of selective serotonin-reuptake inhibitors during pregnancy and the risk of clubfoot. Epidemiology 2014;25:859-65.
10. Dolk H, Jentink J, Loane M, Morris J, de Jong-van den Berg LT. Does lamotrigine use in pregnancy increase orofacial cleft risk relative to other malformations? Neurology 2008;71:714-22.

11. Ganesan B, Luximon A, Al-Jumaily A, Balasankar SK, Naik GR. Ponseti method in the management of clubfoot under 2 years of age: A systematic review. PLoS One 2017;12:e0178299.

12. Shabtai L, Specht SC, Herzenberg JE. Worldwide spread of the Ponseti method for clubfoot. World J Orthop 2014;5:585-90.

13. Ferreira GF, Stéfani KC, Haje DP, Nogueira MP. The Ponseti method in children with clubfoot after walking age - Systematic review and metanalysis of observational studies. PLoS One 2018;13:e0207153.

14. Bogers H, Rifouna MS, Cohen-Overbeek TE, Koning AHJ, Willemsen SP, van der Spek PJ, et al. First trimester physiological development of the fetal foot position using three-dimensional ultrasound in virtual reality. J Obstet Gynaecol Res 2019;45:280-8.

15. Offerdal K, Jebens N, Blaas HG, Eik-Nes SH. Prenatal ultrasound detection of talipes equinovarus in a non-selected population of 49 314 deliveries in Norway. Ultrasound Obstet Gynecol 2007;30:83844.

16. Shipp TD, Benacerraf BR. The significance of prenatally identified isolated clubfoot: is amniocentesis indicated? Am J Obstet Gynecol 1998; 178:600-2.

17. Bakalis S, Sairam S, Homfray T, Harrington K, Nicolaides K, Thilaganathan B. Outcome of antenatally diagnosed talipes equinovarus in an unselected obstetric population. Ultrasound Obstet Gynecol 2002;20:226-9.

18. Cohen-Overbeek TE, Grijseels EW, Lammerink EA, Hop WC, Wladimiroff JW, Diepstraten AF. Congenital talipes equinovarus: comparison of outcome between a prenatal diagnosis and a diagnosis after delivery. Prenat Diagn 2006;26:1248-53.

19. Mahan ST, Yazdy MM, Kasser JR, Werler MM. Prenatal screening for clubfoot: what factors predict prenatal detection? Prenat Diagn 2014:34:389-93.

20. Di Mascio D, Buca D, Khalil A, Rizzo G, Makatsariya A, Sileo F, et al. Outcome of isolated fetal talipes: A systematic review and metaanalysis. Acta Obstet Gynecol Scand 2019;98:1367-77.

21. Hartge DR, Gaertner S, Weichert J. Prenatal detection and postnatal outcome of congenital talipes equinovarus in 106 fetuses. Arch Gynecol Obstet 2012;286:831-42.

22. Lauson S, Alvarez C, Patel MS, Langlois S. Outcome of prenatally diagnosed isolated clubfoot. Ultrasound Obstet Gynecol 2010;35:708-14.

23. Mammen L, Benson CB. Outcome of fetuses with clubfeet diagnosed by prenatal sonography. J Ultrasound Med 2004;23:497-500.

24. Malone FD, Marino T, Bianchi DW, Johnston K, D'Alton ME. Isolated clubfoot diagnosed prenatally: is karyotyping indicated? Obstet Gynecol 2000;95:437-40.

25. Woodrow N, Tran T, Umstad M, Graham HK, Robinson H, de Crespigny L. Mid-trimester ultrasound diagnosis of isolated talipes equinovarus: accuracy and outcome for infants. Aust N Z J Obstet Gynaecol 1998;38:301-5.

26. Viaris de le Segno B, Gruchy N, Bronfen C, Dolley P, Leporrier N, Creveuil C, et al. Prenatal diagnosis of clubfoot: Chromosomal abnormalities associated with fetal defects and outcome in a tertiary center. J Clin Ultrasound 2016;44:100-5.

27. Tegnander E, Eik-Nes SH. The examiner's ultrasound experience has a significant impact on the detection rate of congenital heart 
defects at the second-trimester fetal examination. Ultrasound Obstet Gynecol 2006;28:8-14.

28. Ester AR, Weymouth KS, Burt A, Wise CA, Scott A, Gurnett CA, et al. Altered transmission of HOX and apoptotic SNPs identify a potential common pathway for clubfoot. Am J Med Genet A 2009;149a:2745-52
29. Menke DB, Guenther C, Kingsley DM. Dual hindlimb control elements in the Tbx4 gene and region-specific control of bone size in vertebrate limbs. Development 2008;135:2543-53.

30. Yang H, Zheng Z, Cai H, Li H, Ye X, Zhang X, et al. Three novel missense mutations in the filamin $B$ gene are associated with isolated congenital talipes equinovarus. Hum Genet 2016;135:1181-9. 